Violence as a Generative Force: Identity, Nationalism, and Memory in a Balkan Community. By Max Bergholz. Ithaca: Cornell University Press, 2016. xvii, 441 pp. Notes. Bibliography. Glossary. Index. Photographs. Maps. \$35.00, hard bound. doi: $10.1017 /$ slr.2018.228

Few issues in Balkan history have been more controversial than the atrocities committed in the Independent State of Croatia (Nezavisna Država Hrvatska, NDH) during World War II. Attempts, some inaccurate and divisive, have been made to record massacres and killings and determine more precisely the number of lives lost, but less attention has been directed to the complex causes. Furthermore, there has been a tendency to examine the low hanging fruit found among records of the most egregious episodes. Likewise, the discussion of atrocities has often been a dichotomy of good versus bad with simplistic explanations for why one side were victims and the other perpetrators.

Having stumbled upon an important collection of previously unutilized documents that pertained to atrocities in and around Kulen Vakuf, Max Bergholz embarked on an unconventional and comprehensive study of murders, thefts, and communal violence that took place in the summer and autumn of 1941. In this original and outstanding micro-history, Bergholz relates the history of Kulen Vakuf, a picturesque village on the banks of the Una River, seeking to determine the antecedents for wartime violence, but discovering that the region was remarkably peaceful and ethnically inclusive. After Yugoslavia was defeated by the Nazis and the Independent State of Croatia was established by Ante Pavelić, the ethnic dynamics in this rural region changed. Driven more by the opportunity to steal and loot than Zagreb policies, newly christened Ustaše and those willfully affiliated with them began terrorizing the local communities in this distant region of Bosnia-Herzegovina. Choosing to fight instead of being victims, an insurgency was organized to oppose the Ustaše and later troops from the NDH who were ordered into the region. The insurgency was not a product of communist organization, in part because there was very little knowledge of communism and no significant impetus for residents to pursue communist ideology. In September 1941, the insurgency struck, costing the lives of Ustaše, NDH troops, and civilians, including women and children. There were some who chose to save others, but a horrific slaughter ensued taking the lives of approximately 2,000. Not content to end the story at the war's conclusion, Bergholz skillfully examines the post-1945 era explaining the legacy of 1941 and how it altered and hardened identities that remain significant components of the political landscape of the region.

Bergholz's most noteworthy finding is that ethnic rivalry was not the principle source of violence in 1941, but ethnic identity and its concomitant nationalism arose from the extreme violence of that year. This recasts the arguments that traditionally emphasized ethnic division as having been deeply imbued by imperial policies and many other factors, ultimately reaching a breaking point that led to the atrocities in Croatia. Instead, Bergholz argues that the ethnic divisions were fueled by the process of violence that erupted in and around Kulen Vakuf. The Ustaše and their followers had been driven into ethnic identity, because there were clear material advantages to joining Ante Pavelić's movement. The galvanization of ethnic identity was a product of immediacy and the more violence that ensued the deeper the ethnic divisions became. Furthermore, the violence in this small village in 1941 created a multitude of essentially new identities. These were sometimes forged into single national identities, especially in the postwar era.

Bergholz's intricate and painstakingly-crafted study, deeply imbued with comprehensive archival work in Bosnia-Herzegovina, Croatia, and Serbia, forces historians to reexamine their previous notions of communal violence in World War II Yugoslavia as well as many other places where judgment to blame preexisting ethnic tensions 
has become standard and accepted interpretations. In many ways, Bergholz's wellcrafted micro-history is a call for more careful studies of the origins of violence and how violence manipulates identity. There is no doubt that Violence as a Generative Force will became a standard source for all seeking to understand the connections between identity and violence.

ROBERT B. MCCORMICK University of South Carolina Upstate

\section{Slavs in Post-Nazi Austria: Carinthian Slovenes and the Politics of Assimilation, 1945-1960. By Robert Knight. London: Bloomsbury Academic, 2017. xiii, 249 pp. Notes. Bibliography. Glossary. Index. Tables. £85.00, hard bound.} doi: 10.1017/slr.2018.229

This focused, readable and important monograph traces the history of the Slovene minority in the southern Austrian province of Carinthia over the past 150 years. Robert Knight begins with a lament expressed by poet Urban Jarnik in 1826 that thousands of Slovenes had been absorbed over the centuries into German culture and no end seemed in sight. Yet unlike other Slavic groups that once vanished in culturally German seas of Pomerania, Lower Silesia, or what is now eastern Germany, the Slovene minority persists.

Yet the challenges have been tremendous and the assimilation often far from peaceful. During the Habsburg years, Slovene identity found a political structure in the Catholic People's Party, but that in the eyes of German liberals, socialists, or agrarians only made these "Wends" seem a backward sect particularly in need of German culture. An 1867 nationality law provided for bilingual education but was pushed back, and a wave of repression struck during WWI. Still, the conflict was not as severe as in the Czech lands, and among Slovene speakers a strong local patriotism prevailed, causing most to oppose inclusion in the Yugoslav state of 1918.

From 1938, the Nazi regime tried to smother Slavic identity by closing Slovene language schools and deporting Slovene nationalists, but after 1945 people asked what Austria should do to protect Slavic speakers after ravages bordering on genocide. The politician Joško Tischler came up with a plan to bypass the tricky question of who exactly belonged to the minority: every child in southern Carinthia would be educated in Slovene and German for the first four years, and then switch to German while maintaining Slovene as a compulsory subject. That would have represented historic justice and put an end to fears that Slovene might disappear entirely.

Yet before long resistance reared its head. Some Germans argued the arrangement would confuse the children; others said there were not enough teachers. But still, agreement persisted that knowing both languages was of benefit, and one socialist said that ignorance of Slavic languages had always been a misfortune for Germans. In October 1945 the provisional Carinthian government passed the provision.

Unfortunately, Tischler left his post, in part for his failure to gain support from Yugoslav separatists in Carinthia (the Liberation Front, OF), and bilingual education was marginalized. Two years later any leverage Yugoslavia had was extinguished in the Tito-Stalin feud, when the Soviet Delegation in Paris dropped Yugoslav's concerns about Croats and Slovenes in Austria.

On the ground in Austria, British authorities moved to consolidate the "western" camp, and because communists most vocally supported justice for crimes against Slovenes, efforts at restitution for wartime persecutions now took a back seat. Expellees who returned got compensation, but former Nazis flowed back into teaching, and a 